\title{
ŚWIADCZENIE USEUG FARMACEUTYCZNYCH W APTEKACH JAKO UDZIELANIE ŚWIADCZEŃ ZDROWOTNYCH
}

\section{WPROWADZENIE}

Normatywny rozdział zawodów lekarza i farmaceuty w naszym kręgu kulturowym zapoczatkowano dopiero w XII i XIII w. W następnych stuleciach aptekarze nadal jednak podejmowali się wykonywania czynności lekarskich, a lekarze zajmowali się sporządzeniem i zbywaniem leków. Czasem nawet prowadzili apteki ${ }^{1}$. Warto rozważyć, w jakim stopniu czynności fachowego personelu aptek ${ }^{2}$ noszą cechy działań podmiotów wykonujących działalność lecznicza, w szczególności lekarzy, na gruncie współczesnego prawa polskiego. Odpowiedź na to pytanie stanowi bowiem ważki argument przemawiajacy za przyjęciem albo odrzuceniem tezy o uznaniu osoby korzystającej z usług farmaceutycznych w obrocie detalicznym produktem leczniczym za pacjenta w rozumieniu ustawy z 6 listopada 2008 r. o prawach pacjenta i Rzeczniku Praw Pacjenta ${ }^{3}$.

\section{PROWADZENIE APTEKI A WYKONYWANIE DZIAŁALNOŚCI LECZNICZEJ}

Ustawodawca definiuje aptekę jako placówkę ochrony zdrowia publicznego, w której osoby uprawnione świadczą w szczególności usługi farmaceutyczne wyliczone w art. 86 ust. 2 ustawy z 6 września 2001 r. - Prawo farmaceutyczne $^{4}$ (ust. 1 powołanego przepisu). Nie ulega zatem watpliwości, że apteka nie dysponuje zdolnością prawną. Należy uznawać ją za przedsiębiorstwo w znaczeniu przedmiotowym - przyjętym w art. $55^{1}$ Kodeksu cywilnego (k.c.) - lub

${ }^{1}$ Kamiński, Wesołowski (2010): 25-27; Rembieliński, Kuźnicka (1987): 64-100.

${ }^{2}$ Nawiązując do potocznego, a nie normatywnego, znaczenia słowa „aptekarz” - Sobol (1994): 19.

${ }^{3}$ T.jedn.: Dz. U. 2017, poz. 1318 (dalej jako: u.p.p.). Za jej słusznością zdają się opowiadać Wałachowska (2018): 759; Wasilewska (2017): 103. Przeciw niej opowiada się m.in. Zimmermann (2012): 28, kwalifikując taką osobę jako klienta. Podobne stanowisko zajął NSA w wyroku z 5 września 2006 r., II FSK 1081/05, Legalis nr 82022.

${ }^{4}$ T.jedn.: Dz. U. 2019, poz. 499 (dalej jako: pr.far.). 
jego część. Taki sam status ma zorganizowany zespół składników przeznaczonych do wykonywania działalności leczniczej - nawet jeżeli nie prowadzi się jej w celach zarobkowych, lecz $\mathrm{w}$ formie samodzielnego publicznego zakładu opieki zdrowotnej $^{6}$ (art. 16, 205 i art. 218 ust. 2 ustawy z 15 kwietnia 2011 r. o działalności leczniczej ${ }^{7}$ ). Dlatego też uzasadnione wydawać się może uznawanie prowadzenia apteki za wykonywanie działalności leczniczej. Hipoteza ta wymaga weryfikacji.

Watpliwości co do zasadności proponowanej kwalifikacji w odniesieniu do aptek ogólnodostępnych wynikają z katalogu przesłanek odmowy wydania zezwolenia na prowadzenie takiej placówki (obligatoryjnego cofnięcia go). Należy do niego wykonywanie przez dany podmiot działalności leczniczej i złożenie wniosku o wpis do rejestru podmiotów wykonujących działalność leczniczą (art. 100 ust. 2 pkt 5a lit. a, art. 101 pkt 3 oraz art. 103 ust. 1a pr.far.). Ponadto do ostatniego rejestru nie wolno wpisać tego, kto dysponuje wymienionym zezwoleniem albo wystapił o jego wydanie (art. 108 ust. 1 pkt 4 lit. b u.d.l.). Powyższe postanowienia dodano do pr.far. i u.d.l. z dniem 1 sierpnia 2018 r. ${ }^{8}$ Wcześniej podobne ograniczenie dotyczyło jedynie aktywnych zawodowo lekarzy i lekarzy dentystów (art. 99 ust. 4b pr.far.), co może sugerować, że - w założeniu racjonalny - prawodawca, dokonując prezentowanej zmiany stanu prawnego, dążył do wyłączenia świadczenia usług farmaceutycznych w aptece ogólnodostępnej ze zbioru desygnatów pojęcia „wykonywanie działalności leczniczej”.

Słuszność zaprezentowanego rozumowania potwierdza treść uzasadnienia powołanej nowelizacji ${ }^{10}$. Do obrony pozostaje jednak także kierunek wykładni, zgodnie z którym, zmieniając pr.far. i u.d.l. w 2018 r., prawodawca dążył tylko do podkreślenia szczególnego charakteru postanowień pierwszej ustawy względem drugiej, jeżeli chodzi o obrót lekami i wyrobami medycznymi. Przyjęcie go oznacza, że bezpośrednie zaopatrywanie ludności w produkty lecznicze (wyroby medyczne) stanowić może działalność lecznicza, lecz nie stosuje się do niej przepisów u.d.l. w zakresie uregulowanym w pr.far. - zwłaszcza do aptek ogólnodostępnych. Za słusznością drugiej interpretacji przemawia szereg okoliczności. Po pierwsze, zapewnianie pacjentowi leków (wyrobów medycznych) wyliczono wśród przykładowych świadczeń zdrowotnych w rozumieniu u.d.l. (art. 9 ust. 1 pkt $1-2)^{11}$. Po drugie, na lekarzy wykonujących w swoim imieniu działalność

${ }^{5}$ Kwalifikacja w tym zakresie zależy od rodzaju apteki. Samodzielny charakter ma apteka ogólnodostępna (art. 87 ust. 2 pr.far.). Elementem bardziej złożonej struktury jest apteka szpitalna (art. 87 ust. 1 pkt 3 i ust. 2a pr.far.). Kruszyński (2014): 51-52; Naworski (2015): 4-8; Radwański (2003): 3-12; Kaczan (2018): 299, 301.

${ }^{6}$ Kaczan (2018): 85; Banaszczyk (2016): 7-9, 13-14; Nowak-Kubiak (2012): 144-145; wyrok NSA z 1 grudnia 2016 r., I FSK 218/15, Legalis nr 1577535.

7 T.jedn.: Dz. U. 2018, poz. 2190 (dalej jako: u.d.1.).

${ }^{8}$ Na mocy art. 1 pkt 28 lit. a, pkt 29 i pkt 30 lit. a oraz art. 4 pkt 2 ustawy z 7 czerwca 2018 r. o zmianie ustawy - Prawo farmaceutyczne oraz niektórych innych ustaw, Dz. U. poz. 1375.

${ }^{9}$ Nowak (1973): 35 n.; Zachmielewska (2010): 97; Matczak (2015): 102-116; postanowienia SN: z 24 czerwca 2004 r., III CZ 46/04, Legalis nr 254306; z 28 sierpnia 2008 r., V KK 84/08, Legalis nr 117776.

${ }^{10}$ Sejm VIII kadencji, druk nr 2386.

${ }^{11}$ Dercz (2014): 87-88. 
leczniczą inaczej niż wyłącznie w zakładzie leczniczym na podstawie umowy z prowadzącym go podmiotem leczniczym nałożono obowiązek dysponowania produktami leczniczymi koniecznymi do udzielania świadczeń zdrowotnych (art. 18 ust. 1 pkt 3, ust. 2 pkt 1 ust. 3 pkt 2 i ust. 5 u.d.l.) ${ }^{12}$. Po trzecie, legalne pozostaje dokonywana przez lekarzy sprzedaż leków (wyrobów medycznych) w związku z udzieleniem pomocy w nagłym przypadku oraz dokonywanie innych rozporządzeń nimi (art. 46 ust. 1-2 ustawy z dnia 5 grudnia 1996 r. o zawodach lekarza i lekarza dentysty - dalej u.z.l. $\left.{ }^{13}\right)^{14}$. Ponadto bezpośredniego zastosowania u pacjenta produktów leczniczych nie uznaje się jednie za obrót detaliczny lekami, co niekoniecznie oznacza, że działanie to nie stanowi obrotu nimi sui generis (art. 68 ust. 4 pr.far.) ${ }^{15}$. Argumenty podniesione na poparcie drugiego stanowiska wydają się bardziej przekonujące. Przeciwne rozstrzygnięcie badanego problemu prowadzi do wniosku, że kwalifikacja prawna określonego działania medycznego jako przejawu działalności leczniczej zależy od tego, jaki status prawny ma podejmujacy je podmiot. W przeciwieństwie do art. 3 ust. 4 u.p.p., w art. 3 u.d.l. brak takiego kryterium. Nie zastrzeżono go również w definicji legalnej świadczenia zdrowotnego (art. 2 ust. 1 pkt 10 u.d.l. w zw. z art. 3 ust. 1 pkt 6 u.p.p. $)^{16}$.

Funkcjonowanie aptek szpitalnych (ewentualnie działu farmacji szpitalnej - art. 87 ust. 4 pr.far.) zawsze wiąże się z wykonywaniem działalności leczniczej przez jednostki organizacyjne publicznej służby krwi albo podmioty lecznicze zajmujące się udzielaniem stacjonarnych i całodobowych świadczeń zdrowotnych (art. 87 ust. 1 pkt 2 i ust. 2a pr.far.) ${ }^{17}$. Działalność takich aptek obejmuje wszelkie czynności aptek ogólnodostępnych oraz określone w ustawie dodatkowe usługi farmaceutyczne (art. 86 ust. 2-3 pr.far.) ${ }^{18}$, co może przemawiać za słusznością poglądu o kwalifikowaniu prowadzenia przedsiębiorstw ostatniego typu za wykonywanie szczególnego rodzaju działalności

12 Analogiczna powinność dotyczy podmiotów leczniczych w odniesieniu do wyrobów medycznych (art. 17 ust. 1 pkt 2 u.d.1.).

13 T.jedn.: Dz. U. 2019, poz. 537 (dalej jako: u.z.l.).

14 Wyrok NSA z 7 września 1995 r., II SA 855/94, Legalis nr 39610; wyrok WSA w Warszawie z 11 lipca 2005 r., I SA/Wa 1025/04, Legalis nr 73496; Karkowska (2012b): 314; Dyszlewska-Tarnawska (2015): 517-518; Majcher (2008): 665-667; Kaczan (2018): 32-33.

15 Kaczan (2018): 248-249.

16 Paszkowska (2012): 82; Karkowska (2009): 209; Chojecka, Nowak (2016): 76-77; Molęda (2011): 17-19. Przeciwny pogląd prezentuje Dercz (2014): 44. Autor ten podnosi, iż bronione przez niego stanowisko uzasadnia treść art. 17 ust. 1 pkt 3 u.d.l. Gdyby jednak przyjąć, że świadczeniem zdrowotnym są tylko czynności podejmowane przez profesjonalistów, to fragment ostatniego przepisu u.d.l. brzmiący: „zapewniać udzielanie świadczeń zdrowotnych wyłącznie przez osoby wykonujące zawód medyczny" - należałoby uznać za zbędny. Skoro działania medyczne innych ludzi nie spełniałyby przesłanek świadczenia zdrowotnego, to nie istniałaby potrzeba wymagania od podmiotu leczniczego, aby udzielanie ich powierzał tylko odpowiednio wykwalifikowanym członkom swojego personelu. Ponadto odrzucana interpretacja pozbawia praktycznej doniosłości art. 58 u.z.l. stanowiący o udzielaniu świadczeń zdrowotnych bez uprawnień. Należy też zauważyć, że krytykowana wykładnia zdaje się prowadzić do wniosku, że ustawodawca popełnił błąd idem per idem, definiując pojęcie podmiotu wykonującego działalność leczniczą w art. 2 ust. 1 pkt 5 u.d.l. Morawski (2014): 122-124.

17 Ogiegło (2018): 817-818.

18 Świerczyński (2012): 409. 
leczniczej. Zasadność prezentowanego poglądu potwierdza też dopuszczalność zaopatrywania w leki bezpośrednio pacjentów przez personel apteki szpitalnej w przypadkach wyliczonych w art. 106 ust. 3 pkt $2-3$ pr.far. ${ }^{19}$ Wówczas strona stosunku prawnego w tym zakresie nie pozostaje ta placówka (będąca zorganizowanym zespołem składników), lecz nosiciel praw i obowiązków, który ją utworzył ${ }^{20}$.

$\mathrm{Na}$ zakończenie rozważań zawartych w niniejszej części artykułu warto zwrócić uwagę na zasygnalizowane już postanowienie art. 86 ust. 1 pr.far., że każda apteka ma status placówki ochrony zdrowia publicznego. Podstawowy cel jej uruchomienia pozostaje zatem taki sam jak utworzenia zakładu leczniczego podmiotu wykonującego działalność leczniczą uregulowaną w u.d.l. (realizacja dyrektywy wynikajacej z art. 68 ust. 1 Konstytucji RP) ${ }^{21}$. Przeciw prezentowanemu rozumowaniu nie przemawia nawet treść regulacji ustawy z 27 sierpnia 2004 r. o świadczeniach opieki zdrowotnej finansowanych ze środków publicznych ${ }^{22}$, choć na pierwszy rzut oka wydaje się inaczej. Dokonano w nich rozróżnienia na: świadczenia opieki zdrowotnej i świadczeniodawców oraz usługi farmaceutyczne udzielane w aptekach i apteki (względnie „właścicieli aptek”) - m.in.: art. 47c ust. 1 i 5; art. 97a ust. 5; art. 99 ust. 6 pkt 2-3 oraz art. 107 ust. 5 pkt 13. Należy jednak podkreślić odmienności występujace pomiędzy normatywnym znaczeniem pojęcia apteki na gruncie u.ś.o.z. a przyjętym w pr.far. Zakresy desygnatów tej nazwy w rozumieniu obu powołanych ustaw krzyżują się. W u.ś.o.z. słowo „apteka” najczęściej odnosi się do apteki ogólnodostępnej albo punktu aptecznego, o ile Narodowy Fundusz Zdrowia (NFZ) zawarł z podmiotem prowadzącym daną placówkę umowę na wydawanie leku, środka spożywczego specjalnego przeznaczenia żywieniowego oraz wyrobu medycznego objętych refundacją (art. 5 pkt 2 u.ś.o.z.) ${ }^{23}$. Zgodnie z postanowieniami pr.far. apteki oraz punkty apteczne to różne typy placówek obrotu detalicznego produktem leczniczym (art. 68 ust. 1 i art. 70 ust. 1). Ponadto, jak już zauważono, apteka ogólnodostępna nie jest jedynym rodzajem apteki (art. 87 ust. 1 pr.far.). Warto dodać, że do przesłanek uznania danego zespołu składników za aptekę w rozumieniu pr.far. nie zalicza się zawarcie jakiejkolwiek umowy z NFZ ${ }^{24}$.

19 Pacjenci mogą otrzymywać produkty lecznicze z takiej apteki, jeżeli zostali włączeni do terapii w ramach programów lekowych, korzystają z chemioterapii w trybie ambulatoryjnym lub uzyskali zgodę na pokrycie kosztów farmakoterapii w ramach ratunkowego dostępu do technologii lekowej. Kaczan (2018): 299-300.

20 Stefańczyk-Kaczmarczyk (2016): 1042-1052, 1263-1264, 1267-1269; Olszewski (2016): 932-934; Nowak-Chrząszczyk (2016): 1079-1080.

21 Stankiewicz (2014): 480; Ożóg (2010): 350; wyrok NSA z 11 stycznia 2012 r., II GSK 1365/10, Legalis nr 793756. W powołanym rozstrzygnięciu sąd dopuścił jednak swobodne rozszerzanie asortymentu apteki oraz świadczenie w niej dowolnych usług, co jawi się jako wątpliwe z uwagi na brzmienie art. 86 ust. 8-9 pr.far. Wyrażeniem „w szczególności” posłużono się w art. 86 ust. 1 pr.far., by dopuścić prowadzenie w tej placówce działalności dodatkowej, ale wyłącznie w przypadkach wyraźnie określonych przez ustawodawcę (niekoniecznie w pr.far.) - Kaczan (2018): 302-304.

22 T.jedn.: Dz. U. 2018, poz. 1510 (dalej jako: u.ś.o.z.).

${ }^{23} \mathrm{~W}$ ustawie tej mowa też o aptekach w kontekście zagranicznych przedsiębiorstw detalicznego obrotu farmaceutycznego - art. 97a ust. 6.

${ }^{24}$ Urban (2018): 61-63. 


\section{USEUGI FARMACEUTYCZNE JAKO ŚWIADCZENIA ZDROWOTNE}

Istotą funkcjonowania apteki jest świadczenie usług farmaceutycznych. Przed udzieleniem odpowiedzi na pytanie sformułowane w ramach uwag wstępnych należy więc rozważyć, czy działalność ta spełnia przesłanki podstawowego sposobu wykonywania działalności leczniczej, czyli udzielania świadczeń zdrowotnych (art. 3 ust. 1 u.d.l.) ${ }^{25}$.

Ustawowy katalog usług farmaceutycznych nie ma charakteru zamkniętego ${ }^{26}$. Legalną definicję cząstkową tego pojęcia (posłużono się w niej wyrażeniem „w szczególności”) ${ }^{27}$ zawiera art. 2a ust. 1 ustawy z 19 kwietnia $1991 \mathrm{r}$. o izbach aptekarskich ${ }^{28}$. Wyliczone w nim czynności łączy okoliczność, że do poprawnego wykonywania ich potrzebna jest pogłębiona wiedza z zakresu nauk farmaceutycznych (m.in. znajomość skutków zdrowotnych stosowania, zasad przechowywania i oceny jakości produktów leczniczych) oraz umiejętności niezbędne do prawidłowego sporządzania leków aptecznych i recepturowych ${ }^{29}$. Podobne cechy ma definicja legalna „świadczenia zdrowotnego" zawarta w art. 2 pkt 10 u.d.l. Na mocy ostatniego przepisu do desygnatów tego pojęcia zaliczają się działania medyczne, czyli dotyczące konkretnego człowieka i wymagające szczegółowej znajomości fizjologicznych funkcji organizmu człowieka, czynników mogących na nie wpływać oraz sposobów ich modyfikacji, a także fachowych umiejętności (np. interpretacja charakterystyk produktów leczniczych, krytyczna ocena materiałów reklamowych dotyczących leków oraz analiza ewentualnych działań niepożądanych i interakcji między produktami leczniczymi $)^{30}$.

Nie wszystkie usługi farmaceutyczne wykonywane są w aptekach. Przykładowo farmaceuci moga udzielać informacji o lekach (wyrobach medycznych), pracujac w hurtowni farmaceutycznej albo kierować taką placówką (art. 2a ust. 1 pkt 6 i 8 u.i.a.). Prowadzacy ostatnie przedsiębiorstwo nie zaopatruje bezpośrednio ludności w leki (art. 72 ust. 3 in fine pr.far.) ${ }^{31}$. Farmaceuta wykonujący swój zawód w hurtowni farmaceutycznej nie udziela zatem świadczeń zdrowotnych, ponieważ jego działania nie mają charakteru medycznego. Czynności zawodowych nie dokonuje w odpowiedzi na potrzeby zdrowotne poszczególnych ludzi, lecz na zapotrzebowanie podmiotów zaopatrujacych się

25 Paszkowska (2012): 83-84; Chojecka, Nowak (2016): 76-77.

26 Wałachowska (2018): 759.

27 Uzupełnia ona definicję legalną wykonywania zawodu farmaceuty określoną w art. 2a ust. 1-2 powoływanej ustawy. Malinowski (2008): 54; Nawrot (2012): 86-87.

${ }^{28}$ T.jedn.: Dz. U. 2016, poz. 1496 (dalej jako: u.i.a.).

${ }_{29}$ Katzung (2009); Rang et al. (2017): 1; załącznik nr 1 do rozporządzenia Ministra Zdrowia z 16 lutego 2009 r. w sprawie praktyki zawodowej w aptece, Dz. U. Nr 31, poz. 215.

30 Tatoń (2010): 80-81; załącznik nr 1 i 2 do rozporządzenia Ministra Zdrowia z 28 sierpnia 2017 r. w sprawie ramowego programu zajęć praktycznych dla kierunku lekarskiego i lekarsko-dentystycznego, Dz. U. poz. 1728 w zw. z art. 2 ust. 1 u.z.l.

31 Ożóg (2010): 145-146. 
w placówce obrotu hurtowego ${ }^{32}$. Uwagi powyższe dotyczą odpowiednio świadczenia usług farmaceutycznych $\mathrm{w}$ ramach struktury organizacyjnej pozostałych uczestników obrotu hurtowego ${ }^{33}$.

Wykonywania części usług farmaceutycznych w aptekach nie sposób uznać za udzielanie świadczenia zdrowotnego z tych samych powodów, które zostały zauważone w ramach uwag zawartych w poprzednim akapicie. Należą do nich wydawanie produktów leczniczych i wyrobów medycznych: w aptekach szpitalnych na oddziały albo w ramach zaopatrzenia zewnętrznego podmiotu leczniczego (art. 106 ust. 3 pkt 1 pr.far.) oraz w aptekach ogólnodostępnych na podstawie zapotrzebowania podmiotu prowadzącego działalność lecznicza (art. 96 ust. 1 pr.far.). Za działanie medyczne trudno uznać też nadzorowanie przechowywania i utylizacji leków oraz wyrobów medycznych, kierowanie apteka albo działem farmacji szpitalnej oraz współuczestniczenie w sprawowaniu nadzoru nad gospodarką lekami (art. 2 a ust. 1 pkt 5, 8, 9 u.i.a.). Sa to czynności organizacyjne.

Inne usługi farmaceutyczne można kwalifikować jako świadczenia zdrowotne, lecz wyłącznie przy zastrzeżeniu, że spełniają niewymienione wyżej przesłanki określone w art. 2 ust. 1 pkt 10 u.d.l. Zgodnie z przepisem tym działanie medyczne należy do desygnatów definiowanego w nim pojęcia, o ile ma na celu zachowanie, ratowanie, przywracanie lub poprawę zdrowia, ewentualnie wynika z procesu leczenia, względnie zasady wykonywania go uregulowano w przepisach odrębnych.

Jeżeli chodzi o wydawanie produktów leczniczych z apteki przez farmaceutę lub technika farmaceutycznego poszukującemu farmakoterapii (art. 86 ust. 2 pkt 1 pr.far. oraz art. 2 a ust. 1 pkt 3 pr.far.), to mimo pojawienia się w doktrynie odmiennego poglądu, trzeba uznać, że nie ma ono wtórnego charakteru $^{34}$. Nawet $\mathrm{w}$ przypadku zgłoszenia żądania spełnienia świadczenia na podstawie recepty lekarskiej profesjonalista powinien bowiem odmówić dokonania tej czynności, m.in. jeżeli zagrażałoby to zdrowiu lub życiu pacjenta lub zajdzie potrzeba dokonania zmian składu leku recepturowego wykraczających poza jego uprawnienia - o ile nie ma możliwości porozumienia się z osobą dysponującą stosownymi kompetencjami (art. 96 ust. 5 pkt 1 i 4 pr.far.). Każdorazowo musi zatem ocenić skutki zdrowotne wykonania wymienionej usługi farmaceutycznej. Sporządzając lek dla zaspokojenia potrzeb zdrowotnych konkretnej osoby, może modyfikować jego skład z powodu merytorycznych niedoskonałości recepty określonych w przepisach

${ }^{32}$ Należy jednak pamiętać, że - pomimo powyższego - nienależyte prowadzenie obrotu hurtowego może pozostawać w adekwatnym związku przyczynowym ze szkodą doznaną przez tego, kto zaopatrzył się w lek w ramach obrotu detalicznego (art. 36z ust. 1 pr.far. i art. 361 § 1 k.c.) Kaczan (2018): 258-259, 275, 286-287, 292-293, 296; Stefańczyk-Kaczmarczyk (2016): 909-910, 935, 940-944; wyrok SN z 6 września 2018 r., V CSK 608/17, Legalis nr 1823750.

${ }^{33}$ Sa nimi podmioty odpowiedzialne, wytwórcy i importerzy. Zimmermann (2014): 64; Świerczyński (2012): 419; Masełbas (2016): 478-481; Stefańczyk-Kaczmarczyk (2016): 818-821; Kaczan (2018): $277-278$.

${ }^{34}$ Zdaniem Wałachowskiej (2018: 759) przeciwne stanowisko wyraził WSA we Wrocławiu w wyroku z 17 stycznia 2006 r., I SA/Wr 1611/04, Legalis nr 422471. 
wykonawczych ${ }^{35}$. Ponadto farmaceuta powinien - bez konsultacji z lekarzem - wystawić receptę, a nawet wydać bez recepty produkt leczniczy o kategorii dostępności innej niż over the counter (OTC) w razie nagłego zagrożenia zdrowia lub życia pacjenta (art. 96 ust. 3-4 pr.far.). Wobec braku stosownych postanowień przeciwnych ustawy członkowie personelu fachowego apteki podejmuja decyzje w powyższym zakresie samodzielnie na podstawie swojej wiedzy z zakresu nauk farmaceutycznych i informacji o poszukującym farmakoterapii ${ }^{36}$. Stopień ich autonomii w procesie terapeutycznym pozwala uznać, że analizowane działanie spełnia kryterium celu określone w art. 2 ust. 1 pkt 10 u.d.l. Podobną funkcję pełni pielęgniarka. Zwykle wykonuje ona zlecenia lekarskie (art. 4 ust. 1 pkt 5 oraz art. 15 ust. 1 ustawy z 15 lipca 2011 r. o zawodach pielęgniarki i położnej ${ }^{37}$ ), co przypomina realizację recepty lekarskiej przez wydanie leku. Może jednak odmówić tego między innymi ze względu na dobro pacjenta (art. 15 ust. 3 u.z.p.) ${ }^{38}$. Cechą wspólną zawodów pielęgniarki i farmaceuty związaną z wydawaniem produktów leczniczych jest także ograniczona kompetencja do wystawiania recept (art. 15a u.z.p.). Dlatego zaliczenie wykonywania profesji pielęgniarki w ramach jednoosobowej działalności gospodarczej za jedna z organizacyjno-prawnych form prowadzenia działalności leczniczej (art. 5 ust. 2 pkt 2 lit. a u.d.l.) przemawia za taka samą kwalifikacją wykonywania zawodu farmaceuty (zwłaszcza jeśli uwzględni się wyraźne zaliczenie realizacji zleceń lekarskich w procesie diagnostyki, leczenia i rehabilitacji do zbioru desygnatów pojęcia „świadczenie zdrowotne" w art. 4 ust. 1 u.z.p.). Uregulowanie czynności fachowych farmaceutów poza u.d.l. uzasadnia kompleksowy charakter pr.far. ${ }^{39}$

Wiadomości o produktach leczniczych i wyrobach medycznych (art. 86 ust. 2 pkt 4 pr.far.) stanowią informacje dotyczace metod diagnostycznych i leczniczych, a także dających się przewidzieć następstw ich zastosowania albo zaniechania w rozumieniu art. 9 ust. 2 u.p.p. i art. 31 ust. 1 u.z.l. ${ }^{40}$ Przekazywanie ich może zatem stanowić świadczenie zdrowotne jako inne działanie medyczne wynikające z procesu leczenia lub przepisów odrębnych regulujących zasady ich wykonywania ${ }^{41}$. Czynność ta zasadniczo powinna poprzedzać wyrażenie zgody na podjęcie działania medycznego spełniającego przesłanki określone w art. 2

${ }^{35}$ Wyliczono w nich podanie składu produktu leczniczego prowadzącego do niezgodności chemicznej lub fizycznej, względnie do przekroczenia dawki maksymalnej danego surowca farmaceutycznego (bez adnotacji o konieczności zastosowania takiej dawki) - § 4 ust. 2 pkt 3-4 rozporządzenia Ministra Zdrowia z 12 października 2018 r. w sprawie zapotrzebowań oraz wydawania z apteki produktów leczniczych, środków spożywczych specjalnego przeznaczenia żywieniowego i wyrobów medycznych, Dz. U. poz. 2008.

${ }^{36}$ Ożóg (2010): 477-480, 481. Autor słusznie krytykuje stan prawny obowiązujący do 12 grudnia 2015 r., zgodnie z którym przesłanki odmowy wydania leku określało rozporządzenie ministra właściwego do spraw zdrowia (art. 96 ust. 7 pkt 2 pr.far. w ówczesnym brzmieniu). Olszewski (2016): 1000; Molęda (2008): 83-84; Kaczan (2018): 322.

${ }_{37}$ T.jedn.: Dz. U. 2019, poz. 576 (dalej jako: u.z.p.).

38 Karkowska (2013): 140-143.

39 Krekora (2012): 17; Wronkowska, Zieliński (2004): 61-62; Radwański, Olejniczak (2017): 5.

${ }^{40}$ Dudzińska (2008): 91; Karkowska (2012a): 154-155; Kubiak (2017): 292.

41 O ile odnoszą się one do konkretnego człowieka. 
ust. 1 pkt 10 u.d.l. legalizującej oraz poprzedzającej naruszenie dóbr osobistych przez podjęcie diagnostyki, profilaktyki lub leczenia (art. 9 i 16-19 u.p.p. oraz art. 31-35 u.z.l.). Służy realizacji zasady autonomii pacjenta i ogranicza paternalizm przedstawicieli zawodów medycznych ${ }^{42}$. Obowiązku informacyjnego towarzyszącego wydaniu z apteki produktu leczniczego (wyrobu medycznego) nie przewidziano w pr.far. W ograniczonym zakresie ${ }^{43}$ wynika on jedynie z przepisów rozporządzenia wydanego na podstawie art. 96 ust. 9 tej ustawy ${ }^{44}$ ( 55 ust. 1 pkt 5-6 i ust. 2). Podobne rozwiazanie znajduje racjonalne uzasadnienie. Jeżeli dana osoba zgłasza wolę nabycia leku (wyrobu medycznego) wydawanego na podstawie recepty, to niezbędne dane powinna ona już otrzymać od przedstawiciela zawodu medycznego, który receptę wystawił. W przypadku produktów leczniczych (wyrobów medycznych) o kategorii dostępności OTC ten, kto udaje się do apteki, dysponuje informacjami niezbędnymi do podjęcia świadomej decyzji o rozpoczęciu lub kontynuowaniu terapii ${ }^{45}$ albo może łatwo je uzyskać, zwłaszcza dzięki analizie - jawnej - Charakterystyki Produktu Leczniczego (art. 11 ust. 5 pr.far.). Brak konieczności przekazania wyczerpujących danych odnośnie do sposobu działania i dających się przewidzieć skutków stosowania leków (wyrobów medycznych) wynika też z okoliczności, że z aptek wydają je także technicy farmaceutyczni. Do ich uprawnień nie zalicza się udzielanie powyższych informacji (art. 91 pr.far.) ${ }^{46}$. W obowiązujących przepisach nie uwzględniono jednak ryzyka niewłaściwego zrozumienia wiadomości zdobytych samodzielnie przez poszukującego farmakoterapii (wyrobu medycznego) niedysponującego fachową wiedzą.

Wydaje się też, że świadczeniem zdrowotnym jest udzielanie porad dotyczących działania i stosowania produktów leczniczych oraz wyrobów medycznych (art. 2a ust. 1 pkt 6 pr.far.). Przypomina ono ordynowanie ich przez lekarza. Polega bowiem na doradzaniu w doborze metody diagnostycznej, terapeutycznej lub profilaktycznej w zakresie, w jakim pacjentowi wolno podejmować decyzje bez konsultacji z przedstawicielem ostatniego zawodu medycznego ${ }^{47}$. Analizowana usługa farmaceutyczna nie została wyliczona w art. 86 pr.far. jako należąca do zakresu działalności aptek. Nie sposób jednak świadczyć jej w sposób zorganizowany i ciąły poza placówkami bez-

42 Świderska (2007): 17-35, 95-96; Bączyk-Rozwadowska (2011): 59 n.; wyrok SN z 24 września 2015 r., V CSK 738/14, Legalis nr 1372876; wyrok SN z 31 sierpnia 2017 r., V CSK 619/16, Legalis nr 1715286.

43 Obejmuje wiadomości odnośnie do przechowywania, stosowania, środków ostrożności oraz ewentualnych interakcji leku.

44 Powołano je w przyp. 35.

45 Przykładowo z powodzeniem stosował już daną substancję albo mieszaninę dla osiagnięcia takiego samego celu medycznego, zapoznał się z ulotką dołączoną do opakowania, względnie obsługujący go wcześniej farmaceuta przekazał mu odpowiednie wiadomości.

${ }^{46}$ Kruszyński (2011): 26; Ogiegło (2018): 822-823.

${ }^{47}$ Może on swobodnie wybrać produkt leczniczy o kategorii dostępności OTC, a także zastosować odpowiednik leku przepisanego na recepcie lekarskiej (art. 23a ust. 1 pkt 1 i art. 96 ust. 1 pr.far. oraz art. 44 ustawy z 12 maja 2011 r. o refundacji leków, środków spożywczych specjalnego przeznaczenia żywieniowego oraz wyrobów medycznych, t.jedn.: Dz. U. 2017, poz. 1844). Karkowska (2009): 304; wyrok SN z 24 listopada 2011 r., Legalis nr 418094; Pabiańczyk (2014): 23-27, 31. 
pośredniego zaopatrywania ludności w produkty lecznicze. Ponadto spośród uczestników obrotu detalicznego produktami leczniczymi to dla prowadzących apteki - zwłaszcza szpitalne ${ }^{48}$ - zastrzeżono najszerszy zakres czynności fachowych (np. sporządzanie leków aptecznych i recepturowych nie może odbywać się w przedsiębiorstwach, o których mowa w art. 70-71 pr.far. - art. 2 pkt 10 i 12 pr.far. $)^{49}$.

Status nieprzemysłowej produkcji produktów leczniczych w aptekach (art. 86 ust. 2 pkt 2-3 pr.far. oraz art. 2a ust. 1 pkt 4 u.i.a.) zależy od ich kategorii. Lek recepturowy jako przygotowywany dla konkretnej osoby na podstawie recepty lekarskiej (art. 2 pkt 12 pr.far.), jak się zdaje, jest działaniem medycznym wynikającym z procesu leczenia i uregulowanym w odrębnych przepisach w rozumieniu art. 2 ust. 1 pkt 10 u.d.l. ${ }^{50}$ Leki apteczne powstaja natomiast wedle receptury farmakopealnej (art. 2 pkt 10 pr.far.) i moga znajdować się w aptece, zanim ktokolwiek przejawi wolę ich nabycia ${ }^{51}$. Z przepisów pr.far. wynika nawet, że podmiot prowadzący aptekę ogólnodostępną powinien posiadać je w ilości i asortymencie niezbędnym do zaspokojenia potrzeb zdrowotnych miejscowej ludności (art. 95 ust. 1 - lege non distinguente) ${ }^{52}$.

Do usług farmaceutycznych niewyliczonych w art. 86 pr.far. należą ocena jakości produktów leczniczych oraz sprawowanie opieki farmaceutycznej (art. 2 a ust. 1 pkt 2 i 7 u.i.a.). Bez podejmowania pierwszego działania w odniesieniu do otrzymywanych dostaw i zapasów znajdujących się w placówce nie sposób jednak należycie wykonywać zobowiązań w ramach obrotu lekami (art. 355 k.c.). Ponadto kontrolowania stanu produktu leczniczego każdorazowo przy wydaniu go $\mathrm{z}$ apteki wprost wymaga ustawodawca ${ }^{53}$. Ta usługa farmaceutyczna stanowi więc element świadczenia spełnianego na rzecz kontrahenta podmiotu prowadzącego placówkę, polegającego na „właściwym wydaniu” preparatu (art. 96 ust. 8 pr.far.), czyli - uwzględniając wcześniejsze rozważania - świadczenia zdrowotnego ${ }^{54}$. Sprawowanie opieki farmaceutycznej wymaga ścisłej współpracy farmaceuty z pacjentem oraz z przedstawicielami innych zawodów medycznych, zwłaszcza z lekarzem. Niezbędny poziom koordynacji działań tych osób trudno osiagnąć poza apteka szpitalna, zatem legalność sprawowania jej w innym miejscu zdaje się dyskusyjna, biorąc pod uwagę brzmienie wstępu do wyliczenia zawartego w art. 86 ust. 3 pr.far. w zw. z pozostałymi jednostkami redakcyjnymi ostatniego przepisu ${ }^{55}$. Warto zauwa-

48 O ile przyjąć, że zaopatrywanie w nich pacjentów na zasadach określonych w art. 106 ust. 3 pkt 2-3 pr.far. stanowi obrót tego rodzaju - Kaczan (2018): 299-300; Kruszyński (2014): 27-33.

49 Wałachowska (2018): 767-768; Kaczan (2018): 303.

50 Stosowne regulacje zawiera rozporządzenie Ministra Zdrowia z 18 października 2002 r. w sprawie podstawowych warunków prowadzenia apteki, Dz. U. poz. 1565 - zwłaszcza $§ 6$ ust. 3 .

${ }^{51} \mathrm{~W}$ art. 86 ust. 2 pkt 3 pr.far. w przeciwieństwie do pkt 3 tej samej regulacji brak zastrzeżenia odnoszącego się do czasu, jaki powinien upłynąć od sporządzenia produktu leczniczego do wydania go zainteresowanemu.

52 Zieliński (2016): 84-85; Morawski (2014): 123-124; Kaczan (2018): 302, 314-315.

${ }^{53}$ Stosowne postanowienie zawiera $§ 5$ ust. 1 pkt 1 rozporządzenia powołanego w przyp. 35.

54 Dybowski, Pyrzyńska (2013): 186-200; Olszewski (2016): 995-996; Kruszyński (2014): 225; Kaczan (2018): 303.

55 Kaczan (2018): 303. 
żyć, że w myśl art. 2 a ust. 1 pkt 7 u.i.a. to farmaceuta czuwa nad poprawnym przebiegiem farmakoterapii dla uzyskania jej efektów korzystnie wpływających na jakość życia pacjenta, lecz nie sprecyzowano, w jaki sposób. Mając na względzie analizę roli farmaceuty w ochronie zdrowia ujętą w niniejszym opracowaniu, wydaje się, iż opieka farmaceutyczna polega między innymi na zalecaniu wykorzystania danego produktu leczniczego, udzielaniu wskazówek odnośnie do właściwego sposobu jego podawania, przechowywania i dobrania dawki terapeutycznej oraz na podejmowaniu decyzji o wydawaniu z apteki egzemplarzy substancji albo mieszaniny. Cele stosowania leków określa art. 2 pkt 32 pr.far. Należą do nich postawienie diagnozy, przywrócenie, poprawa lub modyfikacja fizjologicznych funkcji organizmu. Odpowiadaja one kryteriom uznania konkretnego działania medycznego za świadczenie zdrowotne w rozumieniu u.d.l. Dlatego sprawowanie opieki farmaceutycznej trzeba kwalifikować jako udzielanie takiego świadczenia ${ }^{56}$.

Ze względu na ograniczoną objętość artykułu pominięto pozostałe usługi farmaceutyczne. Rozważania ujęte w niniejszej pracy pozwalaja jednak udzielić odpowiedzi na pytanie sformułowane w ramach uwag wstępnych.

\section{WNIOSKI}

Zawód farmaceuty można określić jako samodzielny, pomimo braku w pr.far. oraz u.i.a. regulacji podobnej do art. 2 u.z.p. Świadczą o tym kompetencje jego przedstawicieli do efektywnego wpływania na dobór i przebieg farmakoterapii (niekiedy nawet wbrew zaleceniom lekarskim ${ }^{57}$ ) oraz inicjowania jej. Brak obowiązku informacyjnego poprzedzającego usługę farmaceutyczna nie przemawia przeciw słuszności prezentowanego stanowiska. Przekazywanie stosownej wiedzy o produktach leczniczych (wyrobach medycznych) zalicza się bowiem do czynności charakterystycznych dla wykonywania analizowanego zawodu (art. 2 a ust. 1 pkt 6 u.i.a.) ${ }^{58}$. Farmaceuci powinni więc podzielić się nią z nabywca przedmiotu wydawanego, jeżeli zgłosi on takie żądanie (art. 355 k.c. w zw. z art. 86 ust. 2 pkt 4 pr.far.). Zasadność bronionej tezy potwierdza też zastrzeżenie nieprzemysłowego sporządzania leków dla fachowego personelu aptek. Pomimo powyższego oraz okoliczności, że współczesna medycyna oparta jest na wykorzystywaniu produktów leczniczych jako podstawowego środka służącego osiagnięciu celu medycznego ${ }^{59}$, to lekarze pełnią najistotniejszą rolę w ochronie zdrowia. Uprawnienia farmaceutów nie obejmują bowiem bezpośredniego stosowania leków, wyrobów medycznych ani dokonywania zabiegów medycznych.

${ }^{56}$ Ożóg (2010): 361-363; Karkowska (2012b): 94-98 i powołane tam orzecznictwo.

${ }^{57}$ Uchwała SN z 26 października 2011 r., III CZP 58/11, Legalis nr 375553.

58 Konweniuje to, jak się wydaje, z okolicznościa, iż wykonywać go mogą osoby, które ukończyły studia w szkole wyższej na kierunku farmacja (art. $2 b$ u.i.a.).

${ }_{59}$ Rang et al. (2017): 2. 
Technika farmaceutycznego trudniej nazwać samodzielnym zawodem medycznym $^{60}$. Jego przedstawicielom wolno świadczyć usługi farmaceutyczne tylko wyraźnie określone w ustawie. Nie zaliczaja się do nich sprawowanie opieki farmaceutycznej, udzielanie porad i informacji o produktach leczniczych (wyrobach medycznych). Nie mogą oni też podejmować decyzji o wydaniu leku bez recepty ani wystawić recepty farmaceutycznej w stanach nagłych. Niewatpliwie wynika to z ich niższych niż uzyskane przez farmaceutów kwalifikacji. Rola techników farmaceutycznych w ochronie zdrowia jest jednak również istotna. Wolno im wydawać produkty lecznicze, sporządzać je w aptece oraz odmówić wydania leku, gdyby zagrażało to życiu pacjenta ${ }^{61}$.

Mając powyższe na uwadze, apteka jawi się zespołem składników przeznaczonych do prowadzenia działalności leczniczej sui generis. Wyjątkowy charakter placówki wynika ze specyfiki usług farmaceutycznych, która wymaga odrębnej regulacji prawnej.

Konkludując, człowiek zwracajacy się do fachowego personelu apteki o spełnienie niektórych świadczeń lub korzystający z nich ma status pacjenta w rozumieniu u.p.p. Oznacza to, że farmaceuci i technicy farmaceutyczni, wykonując zawód w powyższych placówkach, powinni m.in.: dochowywać należytej staranności (art. 8 u.p.p.), postępować zgodnie z aktualną wiedza medyczną (art. 6 ust. 1 u.p.p.), przyjmować zgłoszenia działań niepożądanych produktów leczniczych (art. 12a u.p.p.), zachować w tajemnicy informacje związane z pacjentem (art. 13 i n. u.p.p.) oraz szanować godność i intymność pacjenta (art. 20 i n. u.p.p.). Pogląd ten znajduje uzasadnienie aksjologiczne. Korzystający z usług farmaceutycznych często darzą szczególnym zaufaniem świadczących je profesjonalistów. Ponadto konweniuje on z przepisami pr.far., w których mowa o pacjencie w kontekście podmiotu poszukującego farmakoterapii (np. art. 86 ust. 2 pkt 2, ust. 3 pkt 3a i ust. 4 pkt 2; art. 95 ust. 3 oraz art. 96 ust. 5 pkt 1).

Damian Kaczan

Uniwersytet Mikołaja Kopernika w Toruniu

502146@doktorant.umk.pl

https://orcid.org/0000-0002-1741-0669

Banaszczyk, Z. (2016). Formy prowadzenia działalności leczniczej. Studia Prawa Prywatnego 11(3/4): 3-40.

Bączyk-Rozwadowska, K. (2011). Prawo pacjenta do informacji według przepisów polskiego prawa medycznego. Studia Iuridica Toruniensia 9(9): 59-100.

Chojecka M., Nowak, A. (2016). Telemedycyna na tle polskich regulacji prawnych - szansa czy zagrożenie? Kwartalnik Antymonopolowy i Regulacyjny 5(8): 74-81 [Online: https://ikar. wz.uw.edu.pl/numery/39/74.pdf].

Dercz, M. (2014). Komentarz do art. 2 i 11, [w:] M. Dercz, T. Rek (red.), Ustawa o działalności leczniczej: Komentarz. Warszawa: 27-55, 86-88.

${ }^{60}$ Zwłaszcza jeżeli nie dysponuje on dwuletnią praktyką - Wałachowska (2018): 760-761;

Karkowska (2012b): 96-97.

${ }^{61}$ Karkowska (2012b): 96-97; Kruszyński (2011): 26. 
Dudzińska, A. (2008). Wymagana informacja udzielana pacjentowi. Państwo i Prawo 63(8): 90-102.

Dybowski, T., Pyrzyńska, A. (2013). Świadczenie, [w:] E. Łętowska (red.), System prawa prywatnego. Tom 5: Prawo zobowiązań - część ogólna. Warszawa: 183-308.

Dyszlewska-Tarnawska, A. (2015). Komentarz do art. 46, [w:] L. Ogiegło (red.), Ustawa o zawodach lekarza i lekarza dentysty: Komentarz. Warszawa: 517-530.

Kaczan, D. (2018). Cywilnoprawne aspekty prawa farmaceutycznego. (Niepublikowana rozprawa doktorska). Torun.

Kamiński, Z., Wesołowski, M. (2010). O dawnych aptekach. Farmacja Polska 6(1): 25-36.

Karkowska, D. (2009). Prawa pacjenta. Warszawa.

Karkowska, D. (2012a). Ustawa o prawach pacjenta i Rzeczniku Praw Pacjenta: Komentarz. Warszawa.

Karkowska, D. (2012b). Zawody medyczne. Warszawa.

Karkowska, D. (2013). Prawo medyczne dla pielęgniarek. Warszawa.

Katzung, B.G. (2009). Introduction, [w:] B.G. Katzung, S.B. Masters, A.J. Trevor (eds.), Basic and Clinical Pharmacology. New York: 1-13.

Krekora, M. (2012). Zakres regulacji, [w:] M. Krekora, M. Świerczyński, E. Traple (red.), Prawo farmaceutyczne. Warszawa: 17-21.

Kruszyński, R.J. (2011). Uprawnienia zawodowe farmaceutów. Aptekarz Polski 6(54/32e): 26-29.

Kruszyński, R.J. (2014). Obrót detaliczny lekami: Zagadnienia prawne. Warszawa.

Kubiak, R. (2017). Prawo medyczne. Warszawa.

Majcher K. (2008). Komentarz do art. 46, [w:] E. Zielińska (red.), Ustawa o zawodach lekarza i lekarza dentysty: Komentarz. Warszawa: 663-667.

Malinowski, A. (2008). Redagowanie tekstu prawnego: wybrane wskazania logiczno-językowe. Warszawa.

Sobol, E. (red.) (1994). Mały słownik języka polskiego. Warszawa.

Masełbas, W. (2016). Komentarz do art. 36z, [w:] M. Kondrat (red.), Prawo farmaceutyczne: Komentarz. Warszawa: 477-482.

Matczak, M. (2015). Argumentum ad absurdum w uzasadnieniu decyzji stosowania prawa a założenie o racjonalności ustawodawcy - analiza krytyczna, [w:] I. Rzucidło-Grochowska, M. Grochowski (red.), Uzasadnienia decyzji stosowania prawa. Warszawa: 102-115.

Molęda, S. (2008). Prawo dla aptek i farmaceutów. Warszawa.

Molęda, S. (2011). Działalność lecznicza lekarzy. Warszawa.

Morawski, L. (2014). Zasady wykładni prawa. Toruń.

Naworski, J.P. (2015). Przedsiębiorca i przedsiębiorstwo w polskim prawie prywatnym (cz. I). Przegląd Prawa Handlowego 24(8): 4-12.

Nawrot, O. (2012). Wprowadzenie do logiki dla prawników. Warszawa.

Nowak, L. (1973). Interpretacja prawnicza. Studium z metodologii prawoznawstwa. Warszawa.

Nowak-Chrząszczyk, B. (2016). Komentarz do art. 106, [w:] W.L. Olszewski (red.), Prawo farmaceutyczne: komentarz. Warszawa: 1077-1085.

Nowak-Kubiak, J. (2012). Ustawa o działalności leczniczej: komentarz. Warszawa.

Ogiegło, L. (2018). Komentarz do art. 91, [w:] L. Ogiegło (red.), Prawo farmaceutyczne: komentarz. Warszawa: 822-823.

Olszewski, W.L. (2016). Komentarz do art. 87 i art. 96, [w:] W.L. Olszewski (red.), Prawo farmaceutyczne: Komentarz. Warszawa: 930-935, 991-1001.

Ożóg, M. (2010). System handlu produktem leczniczym i produktami pokrewnymi: problematyka prawna. Warszawa.

Pabiańczyk, M. (2014). Uwarunkowania prawne realizacji substytucji leków przez apteki. Przegląd Prawa Publicznego 8(9): 23-33.

Paszkowska, M. (2012). Lekarskie praktyki zawodowe w świetle ustawy o działalności leczniczej. Przegląd Prawa Publicznego 6(2): 82-95.

Radwański, Z. (2003). Podmioty prawa cywilnego w świetle zmian kodeksu cywilnego przeprowadzonych ustawą z dnia 14 lutego 2003 r. Przegląd Sądowy13(7/8): 3-23.

Radwański, Z., Olejniczak, A. (2017). Prawo cywilne - część ogólna. Warszawa.

Rang, H.P. et al. (2017). Rang i Dale: Farmakologia. Tłum. E. Bałkowiec-Iskra et al. Wrocław.

Rembieliński, R., Kuźnicka, B. (1987). Historia farmacji. Warszawa. 
Stankiewicz, R. (2014). Model racjonalizacji dostępu do produktu leczniczego: zagadnienia publicznoprawne. Warszawa.

Stefańczyk-Kaczmarczyk J. (2016). Komentarz do art. 87 i art. 106, [w:] M. Kondrat (red.), Prawo farmaceutyczne: komentarz. Warszawa: 1039-1053, 1262-1271.

Świderska, M. (2007). Zgoda Pacjenta na zabieg medyczny. Torun.

Świerczyński, M. (2012). Obrót produktami leczniczymi oraz wymagania dotyczące podmiotów prowadzacych obrót, [w:] M. Krekora, M. Świerczyński, E. Traple, Prawo farmaceutyczne. Warszawa: 390-452.

Tatoń, J. (2010). Lekarz - co to znaczy w XXI wieku? [w:] J. Majkowski (red.), Wyzwania XXI wieku: Ochrona zdrowia i kształcenie medyczne. Warszawa: 79-100.

Urban, K. (2018). Komentarz do art. 5, [w:] A. Pietraszewska-Macheta (red.), Ustawa o świadczeniach opieki zdrowotnej finansowanych ze środków publicznych: komentarz. Warszawa: $51-123$

Wałachowska, M. (2018). Szczególne świadczenia udzielane przez farmaceutów, [w:] L. Bosek, A. Wnukiewicz-Kozłowska (red.), System prawa medycznego. Tom 2: Szczególne świadczenia zdrowotne. Warszawa: 757-781.

Wasilewska, E. (2017). Zobiektywizowany sposób oceny rozmiaru krzywdy przy ustalaniu zadośćuczynienia pieniężnego na rzecz poszkodowanego pacjenta. Ius Novum 11(3): 101-121.

Wronkowska, S., Zieliński, M. (2004). Komentarz do zasad techniki prawodawczej. Warszawa.

Zachmielewska, O. (2010). Upadłość konsumencka w świetle domniemania racjonalności ustawodawcy. Państwo i Prawo 65(11): 96-107.

Zieliński, W. (2016). Komentarz do art. 2 pkt 10-12, [w:] M. Kondrat (red.), Prawo farmaceutyczne: komentarz. Warszawa: 84-85.

Zimmermann, A. (2014). Badanie roli oraz ocena funkcjonowanie apteki ogólnodostępnej w polskim systemie ochrony zdrowia w świetle prawa farmaceutycznego. Annales Academiae Medicae Gedanensis. Gdańsk.

Zimmermann, A. (2012). Status prawny apteki w kontekście ochrony zdrowia. Czasopismo Aptekarskie 21: 25-31.

\section{THE PROVISION OF PHARMACEUTICAL SERVICES IN PHARMACIES AS THE PROVISION OF HEALTH SERVICES}

\section{Sum mary}

The article is aimed at resolving doubts regarding whether people who seek pharmaceutical services in pharmacies can be assigned the status of patients within the meaning of the Patient Rights and the Patient Rights Ombudsman Act. The article presents a historical justification for granting the professional staff working at pharmacies the competence to undertake activities similar to medical assistance. Common features of pharmacies and health care facilities are also specified. This analysis leads to the conclusion that the professional provision of pharmaceutical services can be regarded as performing a specific type of medical treatment. Furthermore the basic professional activities carried out in pharmacies are analysed in the context of the fulfillment of premises for health benefits within the meaning of the Medical Activity Act. This research justifies the conclusion that some pharmaceutical services have the status of providing health benefits and people who seek pharmaceutical services in pharmacies are most often patients.

Keywords: apothecary; physician; pharmacy; pharmaceutical service; health benefit 
